\title{
Evaluation of California's Rangeland Water Quality Education Program
}

\author{
Stephanie Larson, ${ }^{1}$ Kelly Smith, ${ }^{2}$ David Lewis, ${ }^{3}$ \\ John Harper, ${ }^{4}$ and Melvin George ${ }^{5}$ \\ Authors are ${ }^{1}$ Livestock and Range Management Advisor, University of California Cooperative Extension, \\ 133 Aviation Blvd, Suite 109, Santa Rosa, CA 95403-2894; ${ }^{2}$ Graduate Research Assistant, Rangeland Resources \\ Department, Oregon State University, Corvallis, OR 97333; ${ }^{3}$ Watershed Management Advisor, University of California \\ Cooperative Extension, 133 Aviation Blvd, Suite 109, Santa Rosa, CA 95403-2894; ${ }^{4}$ Livestock, Range and Natural \\ Resources Advisor, University of California Cooperative Extension, 579 Low Gap Road, Ukiah, CA 95482; \\ and ${ }^{5}$ Range Management Specialist, University of California, One Shields Ave, Davis, CA 95616.
}

\begin{abstract}
The University of California Cooperative Extension surveyed rangeland owners and managers who attended California's Ranch Water Quality Planning (RWQP) Short Course in 1995-2002. The survey evaluated the effectiveness of this industry-supported voluntary program by evaluating indicators for short course impacts, including 1) rancher participation in the short courses, 2) completion of nonpoint source self-assessments, 3) completion of ranch water quality plans, and 4) implementation of best management practices (BMPs). This report describes the RWQP short course and ranch water quality plan content including the nonpoint source pollution self-assessment and monitoring. Questionnaires were mailed to 777 short course participants on 5 August 2002 (Round 1). A second survey (Round 2) was mailed to nonrespondents on 7 April 2003 . Round 1 and 2 surveys resulted in a $52.9 \%$ total adjusted response rate. Citing privacy issues, 28 respondents refused to complete the survey. Round 1 respondents had a significantly higher rate of BMP implementation, but Round 2 respondents invested more personal funds in BMPs. There was a significant relationship $(P<0.001)$ between plan completion and implementation of BMPs. While the majority of the respondents completed ranch water quality plans and self-assessments, and implemented BMPs, less than $50 \%$ of the respondents implemented a monitoring program. Fifty percent of the respondents raised beef cattle, and the majority managed ranches less than 5000 acres in size. The results of this survey suggest that industry-initiated, voluntary programs supported by education are effective in helping rangeland owners and managers address nonpoint source pollution on their properties. In addition, social surveys are a viable method for landowners to confidentially self-document identified pollution sources and BMP implementation, and to avoid formal reporting to regulatory agencies.
\end{abstract}

\section{Resumen}

El Servicio de Extensión Cooperativa de la Universidad de California entrevistó a propietarios y manejadores de pastizales que asistieron al Curso Corto de Planeación de la Calidad del Agua de los Ranchos de California (RWQP) impartido en $1995-2002$. El estudio evaluó la efectividad de este programa voluntario, financiado por la industria, mediante la evaluación de indicadores de impacto del curso corto que incluían 1) la participación del ranchero en cursos cortos, 2) la conclusión de la autoevaluación de fuentes no puntuales, 3) la conclusión de planes de calidad de agua para el rancho, y 4) la implementación de mejores prácticas de manejo (BMPs). Este reporte describe el contenido del curso corto RWQP y los planes de calidad de agua de los ranchos, incluyendo la autoevaluación y monitoreo de las fuentes no puntuales de contaminación. Los cuestionarios se enviaron por correo el 5 de Agosto del 2002 a 777 participantes del curso (ronda 1). Una segunda entrevista (ronda 2) se envió por correo el 7 de abril del 2003 a los que no respondieron el primer cuestionario. La tasa de respuesta ajustada para la ronda 1 y 2 fue de $52.9 \%$. Citando problemas de privacidad, 28 de los entrevistados se negaron a completar el cuestionario. Los que respondieron en la ronda 1 tuvieron una tasa significativamente mayor de implementación de BMP, pero los que respondieron en la ronda 2 invirtieron mas fondos personales en BMP. Hubo una relación significativa $(P<0.001)$ ente la conclusión de los planes y la implementación de BMP. Mientras que la mayoría de los que respondieron completaron los planes de calidad de agua, las autoevaluaciones e implementación de BMP, menos del 50\% de los que respondieron implementaron un programa de monitoreo. Cincuenta por ciento de los que respondieron el cuestionario criaron ganado de carne, y la mayoría maneja ranchos de menos de 5000 acres. Los resultados de esta encuesta sugieren que los programas voluntarios iniciados por la industria y apoyados por la educación, son efectivos en ayudar a los propietarios y manejadores de pastizales a tratar con fuentes no puntuales de contaminación en sus propiedades. Además, las encuestas sociales son un método viable para los propietarios de tierras para autodocumentar fuentes identificadas de contaminación y la implementación de BMP, y son confidenciales para evitar el reporte formal a las agencias reguladoras.

Key Words: ranch planning, nonpoint source pollution, grazing management, extension education, extension evaluation, public policy education

California's State Water Resources Control Board supported this study with funds authorized by the Federal Clean Water Act, Section 319 .

Correspondence: Stephanie Larson, University of California Cooperative Extension, 133 Aviation Blvd., Suite 109, Santa Rosa, CA 95403-2894. Email: slarson@ucdavis.edu

Manuscript received 6 February 2004; manuscript accepted 11 June 2005. 


\section{INTRODUCTION}

Numerous factors influence changes in practices by range managers. It has been commonly assumed that profit (Workman 1986, White 1987) and perceived risk (Zepada 1994) have a major influence over a manager's decision to implement new practices. Researchers have also found that adoption of new or existing technology by land managers is influenced by age, education, income, goals, size of farm, land tenure, and level of community participation (Huntsinger and Fortman 1990, Fliegel 1993, Coppock and Birkenfeld 1999, Kreuter et al. 2001). Communication of technical information and agency/ industry partnerships have also been associated with the adoption of new practices (Kreuter et al. 2001). Didier and Brunson (2004) described characteristics of innovators, motivations to adopt new practices, and barriers to innovation. In California, the prospect of water quality regulations has resulted in practice changes by range livestock producers.

While the public generally supports programs that manage ecosystems and landscapes to protect water quality, habitat, and biodiversity (Reading et al. 1994, Brunson et al. 1996, Jacobson and Marynowski 1997), landowners generally associate these programs with increased regulation of their land and business (Reading et al. 1994, Lewis 1995, Kraft et al. 1996). Fearing regulation, California's range livestock industry implemented a voluntary program, supported by training, to identify nonpoint sources of pollution and to implement best management practices (BMPs). During the development of this program, 5 evaluation indicators of successful program implementation were developed in collaboration with state advisory committees and regulatory agencies (Gough et al. 1998). These included 1) rangeland owner and manager participation in water quality training, 2) completion of ranch nonpoint source self-assessments, 3) completion of ranch water quality plans, 4) implementation of BMPs proposed in ranch water quality plans, and 5) documentation of BMP effectiveness.

This voluntary program lacks formal reporting of pollution sources and BMPs to state and federal regulatory agencies. Private rangeland owners are resistant to formal reporting of pollution sources and management activities on their property. Federal and state water quality regulatory agencies seek documentation of pollution sources and verification of BMP implementation from private property owners in watersheds that drain into impaired water bodies. We propose that program evaluation surveys are a viable alternative to formal reporting of pollution sources and BMP implementation. Program evaluation surveys have been used to document the development and implementation of ranch plans and grazing management practices (Richards and George 1996) and oak-woodland management practices (Huntsinger et al. 1997) in California. Kreuter et al. (2001) evaluated a brush management research and extension program in Texas, and Fernandez-Gimenez et al. (2005) evaluated a rangeland monitoring extension education program in Arizona. National water quality initiatives have also been evaluated using social survey procedures (EPA 1990, GAO 1995). In this report, we evaluate implementation of this voluntary program by surveying Ranch Water Quality Planning (RWQP) Short Course participants to determine whether they were meeting the evaluation indicators 1-4 above. Because it will take several years or decades to document the effectiveness of the implemented practices, indicator 5 is not included in this evaluation.

\section{RANCH WATER QUALITY PLANNING SHORT COURSE}

State and federal laws provide for voluntary approaches to reduce nonpoint source pollution and California's Non-point Source Pollution Control Program emphasizes self-determined or voluntary pollution prevention (SWRCB 2000). In 1990, California's range livestock industry began to develop a program of voluntary compliance with the Federal Clean Water Act, federal and state coastal zone regulations, and California's Porter-Cologne Act, which provides for regulation of water quality by the State Water Resources Control Board (SWRCB) and 9 Regional Water Quality Control Boards (SWRCB 2004). This livestock industry initiative led to development of the California Rangeland Water Quality Management Plan (CRWQMP) for nonfederal rangelands, which was approved by the SWRCB in 1995 (SWRCB 1995). The CRWQMP, developed in collaboration with regulatory agencies, state advisory committees, private consultants, US Department of Agriculture (USDA) Natural Resources Conservation Service (NRCS), and University of California Cooperative Extension (UCCE), provides for development and implementation of ranch water quality plans on a voluntary basis.

In 1994, UCCE and NRCS began to consider education programs that would support plan development by landowners at a time when they were concerned that state regulations would result in a loss of freedoms and liberties (Huntsinger and Fortman 1990). We decided to implement a user-friendly, nonpoint source pollution training program that addressed the technical aspects of nonpoint source pollution while helping ranchers complete water quality plans. These plans focused on nonpoint source assessment, development of water quality protection objectives, implementation of practices, and monitoring in the short and long-terms. Like Kreuter et al. (2001), we emphasized development and dissemination of user-friendly messages to rangeland managers to increase adoption of ecologically sound rangeland management practices.

In 1995 and 1996, prototypes of the RWQP Short Course were conducted by UCCE and NRCS in Mendocino, Sonoma, Marin, San Luis Obispo, and Plumas Counties. The curriculum developed during the prototype short courses was standardized for course uniformity in September 1997. The target audience for the short course was the owners and managers of nonfederal, primarily privately owned rangelands that are used for livestock production. From September 1997 to August 2002, 51 short courses were conducted in 26 counties with representatives from more than 700 ranches attending.

The short course is a 15 -hour ranch planning course that emphasizes the identification, monitoring, and mitigation of nonpoint sources of pollution on privately owned rangelands. The short course begins by defining and describing nonpoint source pollution, emphasizing sediment, heat (stream temperature), nutrient, and pathogen sources that are most often associated with grazing and ranching. This is followed by a discussion of state and federal water quality regulations and regulatory agencies. The assessment section of the course reviews 
basin water quality assessments and plans, required by the Clean Water Act, that apply to the area in which the short course is held. During this section, short course participants review the impaired water body list required by Section $303 \mathrm{~d}$ of the Clean Water Act (SWRCB 2002), which in California, is titled the Total Maximum Daily Load (TMDL) priority list. Once participants are familiar with state and basin assessments that may affect their property, we ask them to self-assess their own property for sediment, heat, nutrient, and pathogen sources using a checklist (available from the authors). The checklist is reviewed in class using photographic examples of pollution sources. The checklist is divided into three sections: 1) sediment and erosion, 2 ) riparian areas and streams, and 3) nutrients and pathogens.

Following completion of the self-assessment checklist, course participants are asked to review their ranch goals and add new objectives that reflect their self-assessment findings. Armed with management objectives that focus on correcting nonpoint sources of pollution, BMPs are defined and discussed. Rangeland BMPs for California are described in the CRWQMP and in a fact sheet (George and Jolley 1995). Using the terminology and numbering system in the USDA NRCS Field Office Technical Guide, California's rangeland BMPs are divided into 1) Grazing Management, 2) Structural Range Improvements, 3) Land Treatments, and 4) Livestock Management Practices. During the discussion of BMPs, USDA and other cost-share programs are reviewed.

Finally, procedures for monitoring nonpoint sources of pollution on rangelands are described. Because most pollution sources associated with ranching are visible, the short course emphasizes photographic and ocular estimation procedures backed up by good recordkeeping of ranch management activities. Because sediment is the most prevalent pollutant on rangelands and is the target of several coastal TMDLs (Lewis et al. 2001b), a sediment inventory and monitoring procedure was added to the course in 2001 (Lewis et al. 2001a).

Throughout the short course, participants are developing a water quality management plan for their ranch that includes ranch descriptions, ranch goals, ranch maps, basin water quality status, nonpoint source self-assessments, existing and planned BMPs, and monitoring procedures. The short course curricula can be reviewed and downloaded from the following Web address: http://californiarangeland.ucdavis.edu. This Web site can also be reached via the following address: http:// rangelandswest.org.

\section{METHODS}

The CRWQMP targeted nonfederal (mostly private) rangeland owners and managers. The short course targeted larger private landowners and managers but was open to the public and attracted many smaller property owners with small numbers of livestock. The short course was held at the request of county agricultural associations (Farm Bureau, Resource Conservation Districts, and County Cattleman's Association) and conducted jointly by local UCCE Farm Advisors and USDA NRCS Conservationists (Fig. 1). To evaluate the effectiveness of the RWQP Short Course, participants were surveyed by mail (Dillman 2000) to determine their progress toward evaluation indicators 1-4. Address lists of participants were compiled from attendance lists of 51 short courses held in 26 counties

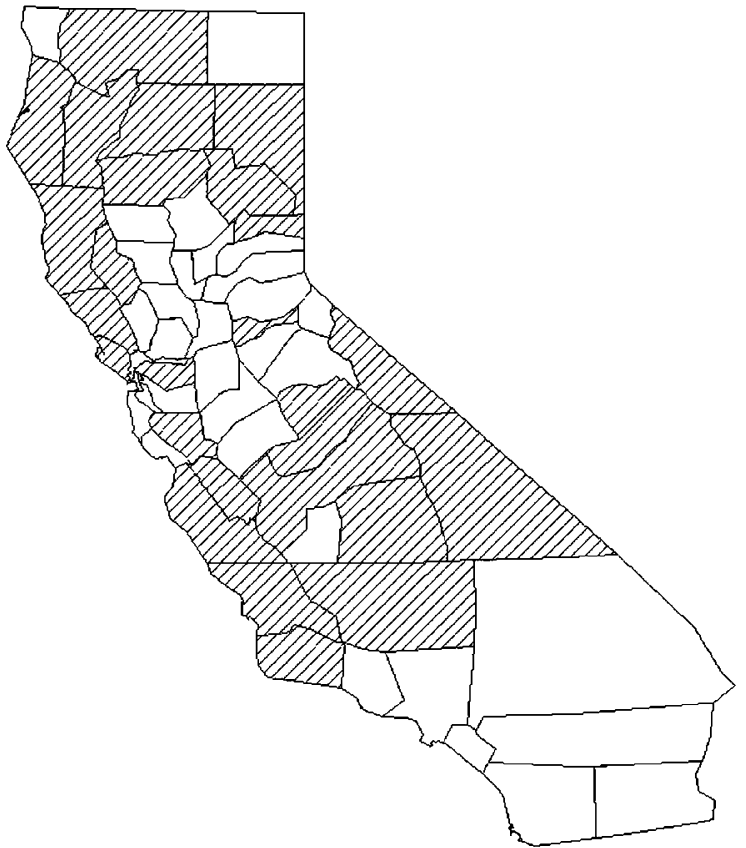

Figure 1. California counties where short courses were held (crosshatched).

between 1995 and 2002 (Fig. 1). The survey was mailed to participants on 5 August 2002 (Round 1). Over the next 4 months, survey returns declined until we mailed a reminder postcard on 9 December 2002 to participants who did not return the survey. The reminder resulted in additional survey returns over the next 4 months, but we also learned that several participants had lost their surveys. Desiring a larger return rate, we contacted nonrespondents by sending a second copy of the original survey on 17 April 2003. We requested an immediate response by 30 April 2003 for inclusion in the survey. Additional surveys were returned during late April, and then returns declined. We started compiling survey results 10 May 2003. Responses to the second survey (Round 2) were compared to responses to the first survey (Round 1) to detect differences between the 2 samples of the short course participant population.

To reduce nonresponse, we discussed early drafts of the survey questionnaire with members of California's Range Management Advisory Committee to the State Board of Forestry and with short course participants who attended the California Cattleman's Association water quality committee. Members of these committees recognized the value of a survey but indicated that the questionnaire should not be long. They also indicated that they did not like questions about age, income, level of education, herd sizes, and property sizes. Consequently, we minimized demographic questions and focused on documenting progress with plan completion, implementation, and related activities.

Short course participants were asked several yes/no questions to determine their progress in completing and implementing a ranch water quality plan. Follow-up multiple choice questions determined 1) acreage class of private and public land that participants managed (i.e., < 500, 500-999, 1 000-2 499, 2 500-4 999, 5 000-9 999, 10 000-14 999, 15 000-19 999, 
Table 1. Comparison of Round 1 and Round 2 responses to yes/no questions regarding planning, implementation, and collaboration.

\begin{tabular}{|c|c|c|c|c|c|c|c|}
\hline \multirow[b]{2}{*}{ Action } & \multicolumn{3}{|c|}{ Round 1} & \multicolumn{3}{|c|}{ Round 2} & \multirow[b]{2}{*}{$\begin{array}{l}\mathrm{R} 1 \text { vs. R2 } \\
\mathrm{S} \quad P\end{array}$} \\
\hline & $\bar{x}^{1}$ & $\mathrm{SE}^{2}$ & $\begin{array}{l}\text { No. of } \\
\text { respondents }\end{array}$ & $\bar{x}$ & SE & $\begin{array}{c}\text { No. of } \\
\text { respondents }\end{array}$ & \\
\hline $\begin{array}{l}\text { Started a ranch water } \\
\text { quality plan }\end{array}$ & 0.89 & .019 & 274 & 0.87 & .033 & 103 & 0.8 \\
\hline $\begin{array}{l}\text { Finished a ranch water } \\
\text { quality plan } \\
\text { Identified nonpoint }\end{array}$ & 0.61 & .03 & 274 & 0.48 & .049 & 103 & $0.03^{3}$ \\
\hline $\begin{array}{l}\text { Identified nonpoint } \\
\text { source pollutants }\end{array}$ & 0.7 & .028 & 272 & 0.68 & .047 & 100 & 0.73 \\
\hline Implemented BMPs & 0.73 & .027 & 271 & 0.53 & .05 & 101 & $0.001^{4}$ \\
\hline $\begin{array}{l}\text { Received cost-share } \\
\text { funding }\end{array}$ & 0.29 & .028 & 266 & 0.31 & .057 & 67 & 0.7 \\
\hline $\begin{array}{l}\text { Participated in } \\
\text { additional education }\end{array}$ & 0.36 & .029 & 272 & 0.33 & .048 & 99 & 0.63 \\
\hline $\begin{array}{l}\text { Participated in } \\
\text { watershed groups }\end{array}$ & 0.43 & .03 & 269 & 0.46 & .051 & 94 & 0.88 \\
\hline
\end{tabular}

${ }^{1} \bar{x}$ Represents averages of yes/no answers, where $0=$ no and $1=$ yes.

${ }^{2} \mathrm{SE}$ indicates standard error.

${ }^{3}$ Significant at $P<0.05$.

${ }^{4}$ Significant at $P<0.01$.

20 000-29 999, 30 000-49 999 and > 50 000), 2) type of livestock managed (beef cattle, sheep, horses, dairy, poultry, other, or none), 3) pollution sources identified during the selfassessment (sediment/erosion, nutrients, pathogens, heat/ stream temperature and riparian/stream damage, or other), 4) personal and cost-share funds invested in BMP implementation or monitoring BMPs $(<\$ 500, \$ 500-999, \$ 1000-1999$, $\$ 2$ 000-5 000, \$5 000-10 000, \$10 000-25 000, \$25 00050000 or $>\$ 50000), 5)$ agency cost-share sources (NRCS, Resource Conservation District, California Department of Fish and Game, or other), 6) additional education programs attended (dairy waste management, forestry practices, road management, endangered species, or other), and 7) occupation (farmer/rancher, agency staff, university personnel, teacher, landowner, or other). Two multiple-choice questions inquired about reasons for taking the short course (to avoid regulation, learn about nonpoint source pollution, support livestock industry water quality initiative, learn about nonpoint source pollution regulations, or other) and reasons for implementing BMPs (to control nonpoint source pollution, to support industry water quality imitative, to avoid regulation, to comply with nonpoint source regulations, or other). The questionnaire provided a blank space to define "other" for each multiplechoice question.

Open-ended questions were asked to determine the kinds of BMPs that had been implemented. The responses to these openended questions were classified into the following categories: riparian management, grazing management, erosion control, water development, water quality control, road management, and crop management.

An adjusted total survey response rate was calculated as follows (AAPOR 2000):

$$
\mathrm{X}=(\mathrm{C}+\mathrm{D}) /(\mathrm{A}-\mathrm{B})
$$

Where $\mathrm{X}=$ adjusted total survey response rate, $\mathrm{A}=$ total surveys mailed, $\mathrm{B}=$ ineligible participants, $\mathrm{C}=$ refusals, and $\mathrm{D}=$ respondents.

Ineligible participants (B) included those whose surveys were returned due to wrong addresses or death, or those who no longer owned or managed rangeland. Respondents (D) were defined as those who completed and returned the questionnaire. Refusals (C) were defined as those who returned the questionnaire but refused to complete it citing privacy.

Logistic modeling was conducted to understand the probability of respondents' implementation of best management practices based on survey responses. Explanatory variables included 1) reasons for attending short course, 2) reasons for implementing BMPs, 3) acres of public land managed, 4) acres of private land managed, 5) personal funds spent on BMP implementation, 6) cost share funds spent on BMP implementation, 7) worked on plan during short course, 8) completed self-assessment, 9) identified nonpoint source pollution during the self-assessment, and 10) completed ranch plan. These variables were selected because the authors believed that they were potential indicators of successful BMP implementation. All statistical analysis was performed using SYSTAT Version 9.0 (SPSS, Inc., Chicago, IL) and Statistical Analysis Systems. Because of the categorical nature of the survey variables, model results provide relative probabilities for a response variable as a function of an explanatory variable.

\section{RESULTS AND DISCUSSION}

\section{Survey Response}

We mailed 777 surveys to participants in the RWQP Short Course from 1995 to 2002. Between 5 August 2002 and 9 December 2002, we received 308 responses, but 469 short course participants did not return the survey because either 1) they forgot or 2) they refused to complete the questionnaire. We mailed a second copy of the same survey to nonrespondents on 17 April 2003, which resulted in 132 additional responses by 30 April 2003.

Combining Rounds 1 and 2, the adjusted total survey response rate was $52.9 \%$. While 440 of the 777 mailed surveys were returned, 60 were ineligible because of wrong addresses, deaths, or the participant was no longer managing the land. Twenty-eight surveys were classified as refusals because they were returned unopened with refusal notes citing privacy or other issues as the reason the survey was not completed. Questionnaires were completed and returned by 352 respondents; 266 during Round 1, and 86 during Round 2.

Respondents to survey Rounds 1 and 2 had similar responses to most of the yes/no questions (Table 1 ). Round 1 respondents had a significantly higher rate for finishing plans and implementing BMPs. However, Round 2 respondents invested significantly more personal funds in BMPs than Round 1 respondents $(P=0.034)$. Refusals to complete the survey increased from $1.3 \%$ of Round 1 to $18.2 \%$ of Round 2 . Most of these refusals were returned, citing reasons of privacy for not completing the survey. This suggests that within the pool of 337 nonrespondents are a substantial number of short course participants who are refusing to complete the survey for privacy or other reasons. Throughout the short course, 
personal and business privacy and private property rights have been an issue for short course participants. While the plans remained in the possession of the short course participants, some participants refused to complete nonpoint source selfassessment checklists or written water quality plans for fear that they would be required to submit them to regulatory agencies, and the plans would become public information. While this remains an issue for some private landowners, short courses continue to attract rangeland owners and managers.

Because the 2 rounds were conducted in a relatively short time frame and both rounds surveyed the same population (Lohr 1999), the 2 rounds were grouped together to evaluate program effectiveness.

\section{Respondent Characteristics}

The short course targeted the owners and managers of large private rangeland holdings. Just over $39 \%$ of the ranches owned or managed by survey respondents were in the 500 to 2500 acre size class, and $30 \%$ of the respondents owned or managed properties greater than 2500 acres in size. By comparison, according to the FRAP (2004), only $16 \%$ of California beef cattle farms are in the 500 to 2000 acre size class, and $12.5 \%$ are in the greater than 2000 acres size class. While this is an imperfect comparison, it does suggest that the short course successfully targeted the owners and managers of larger rangeland holdings while not excluding small landowners. Only half of the respondents operate cow-calf or other beef cattle operations, $19.5 \%$ of the operations had horses, less than $10 \%$ raised dairy cattle or sheep, and less than $7 \%$ indicated that they had no livestock. This is comparable to the findings of Huntsinger and Fortmann (1990), in which $75 \%$ of the 200 to 5000 acre size class produced livestock and $96 \%$ of the greater than 5000 acre class produced livestock. Less than $20 \%$ of the respondents leased public lands for grazing, which is consistent with reports that only $19 \%$ of California's grazed forage comes from public lands (Ewing et al. 1988). The majority of the respondents $(62.8 \%)$ listed their occupation as farmer/rancher, while the rest were agency employees, teachers, or had other occupations. According to the FRAP (2004), only $47 \%$ of nonfeedlot beef cattle producers list their occupation as farmer/rancher. We did not detect any response differences due to acreage class, livestock type, or occupation.

\section{Best Management Practice Implementation}

Survey results indicated that 252 respondents $(67.7 \%)$ implemented BMPs that protect or improve water quality (EPA 2003) (Table 2). Ninety-one percent of the respondents who implemented practices started developing a ranch water quality plan during the short course, and $65 \%$ completed their plans during or immediately following the short course. Of the 120 respondents who did not implement BMPs, $81 \%$ started developing plans during the course, but only $41 \%$ completed their plans.

Logistic modeling was conducted to understand the probability of implementation of best management practices based on survey responses. Four explanatory variables were removed from the model because of blank responses by 68 respondents. These included 1) conducting water quality self-assessment, 2) acres of public land managed, 3) personal funds spent on BMP
Table 2. Reasons cited by respondents who did and did not implement best management practices after taking the Ranch Water Quality Planning Short Course.

\begin{tabular}{lcc}
\hline \multirow{2}{*}{$\begin{array}{l}\text { Reasons for attending } \\
\text { short course }\end{array}$} & \multicolumn{2}{c}{ Implemented best management practices (\%) } \\
\cline { 2 - 3 } & Yes $(n=252)$ & No $(n=120)$ \\
\hline To avoid regulation & 73 & 68 \\
To learn about nonpoint & 72 & 66 \\
$\quad$ source pollution & & 60 \\
To support livestock industry & 68 & \\
$\quad$ water quality initiative & & 57 \\
To learn about nonpoint & 65 & 4 \\
$\quad$ source pollution regulations & 13 & \\
Other reasons & &
\end{tabular}

implementation, and 4) cost-share funds spent on implementation. Explanatory variables that were not significantly $(P=0.05)$ related to BMP implementation were eliminated in a backward stepwise fashion. These included 1) private acreage managed, 2) reasons for attending the short course, 3) started a ranch plan during course, and 4) identified current or potential nonpoint sources of pollution. Six explanatory variables were significantly related to BMP implementation (Table 3). This analysis indicates that plan completion was a strong indicator of BMP implementation. Respondents who identified "control NPS pollution," "support industry efforts," or "avoid regulation" as reasons for BMP implementation were more likely to implement practices than respondents who did not. Respondents who identified other reasons for BMP implementation in an open-ended question were also more likely to implement BMPs than those who did not. It is important to note that although it was removed from the model, identifying nonpoint source pollution had a $P$ value $(P=0.11)$ worth consideration. It is logical that there would be connection between identifying sources of pollution and then implementing practices to address those sources.

A 34-item self-assessment checklist was designed to help landowners and managers identify potential nonpoint sources of pollution that may require monitoring and implementation of BMPs. Respondents reporting that they identified current or potential nonpoint sources of pollution during their self-assessments also reported a high rate of BMP implementation. However, the relationship was not significant $(P>0.05)$. Eighty-one percent of the respondents who implemented BMPs also identified nonpoint sources on their property. Of those who did not implement BMPs, 54\% did not identify nonpoint sources of pollution on their property (Table 4). Only $14 \%$ of the total respondents identified nonpoint sources of pollution during their self-assessment but did not implement BMPs.

Sediment was the leading nonpoint source pollutant identified during self-assessments followed by riparian area damage (Table 5). Nutrient, pathogen, and heat sources were less frequently identified during the nonpoint source self-assessment. BMPs implemented were consistent with the pollutants identified during their self-assessments. With sedimentation and riparian damage being the 2 most cited sources of pollution identified by respondents; BMPs implemented addressed riparian management (38\%), grazing management practices $(33 \%)$, 
Table 3. Results from logistic modeling of participant best management practice implementation.

\begin{tabular}{|c|c|c|}
\hline Explanatory variable & Estimate & $P^{1}$ \\
\hline \multicolumn{3}{|l|}{ Model variables } \\
\hline Intercept & 4.6028 & $<0.0001$ \\
\hline Survey Round 1 or Round 2 & 0.5365 & 0.0345 \\
\hline Finish ranch water quality plan & 0.8770 & 0.0004 \\
\hline \multicolumn{3}{|l|}{ Reasons for implementing $\mathrm{BMPs}^{2}$} \\
\hline To control nonpoint source pollution & -2.2450 & $<0.0001$ \\
\hline To support industry water quality & & \\
\hline management efforts & -1.4430 & $<0.0001$ \\
\hline $\begin{array}{l}\text { To avoid regulatory interference in land } \\
\text { and business decisions }\end{array}$ & -1.4473 & $<0.0001$ \\
\hline Other reasons indicated for implementation & -1.8573 & 0.0007 \\
\hline \multicolumn{3}{|l|}{ Variables not included in the model } \\
\hline County & - & 0.99 \\
\hline Size of private acreage managed & - & 0.28 \\
\hline Manage public lands & - & 0.93 \\
\hline \multicolumn{3}{|l|}{ Reasons for attending the short course } \\
\hline To learn about nonpoint source pollution & - & 0.99 \\
\hline To learn about nonpoint source regulations & - & 0.43 \\
\hline To support industry efforts & - & 0.63 \\
\hline To avoid regulation & - & 0.63 \\
\hline Other & - & 0.78 \\
\hline Worked on plan during short course & - & 0.93 \\
\hline \multicolumn{3}{|l|}{ Portion of ranch plan completed } \\
\hline Introduction & - & 0.97 \\
\hline Facilities & - & 0.32 \\
\hline Assessment & - & 0.26 \\
\hline Monitoring & - & 0.26 \\
\hline Identify types nonpoint sources of pollution & - & 0.11 \\
\hline \multicolumn{3}{|l|}{ Types of nonpoint sources identified } \\
\hline Sediment or erosion & - & 0.65 \\
\hline Nutrients & - & 0.97 \\
\hline Pathogens & - & 0.47 \\
\hline Heat (stream temperature) & - & 0.37 \\
\hline Riparian/stream health & - & 0.50 \\
\hline Other & - & 1.00 \\
\hline \multicolumn{3}{|l|}{ Reasons for implementing BMPs ${ }^{2}$} \\
\hline \multicolumn{3}{|l|}{ To comply with nonpoint source } \\
\hline regulations & - & 0.35 \\
\hline \multicolumn{3}{|l|}{ Source of cost-share funding } \\
\hline National Resource Conservation Service & - & 0.92 \\
\hline Resource Conservation District & - & 0.96 \\
\hline California Department of Fish and Game & - & 0.42 \\
\hline Other & - & 0.96 \\
\hline
\end{tabular}

${ }^{1} P$ values were calculated using the Wald chi-square test for input or predictive variables that were significantly related to a respondent's implementation of best management practices. ${ }^{2}$ BMPs indicates best management practices.

erosion control (33\%), stock water development $(31 \%)$, and road management $(23 \%)$. Riparian management included such practices as restoration plantings, fencing, livestock crossings, and seasonal grazing. In addition to stock water development,
Table 4. Comparison of voluntary program implementation evaluation indicators to respondent implementation of best management practices.

\begin{tabular}{|c|c|c|c|c|}
\hline \multirow[b]{3}{*}{$\underline{\text { Evaluation indicator }}$} & \multicolumn{4}{|c|}{ Implemented best management practices } \\
\hline & \multicolumn{2}{|c|}{ Yes $(n=252)$} & \multicolumn{2}{|c|}{ No $(n=120)$} \\
\hline & Yes $(\%)$ & No $(\%)$ & Yes $(\%)$ & No $(\%)$ \\
\hline Started a ranch water quality plan & 91.3 & 7.9 & 80.8 & 17.5 \\
\hline $\begin{array}{l}\text { Finished a ranch water quality plan } \\
\text { Completed a nonpoint }\end{array}$ & 65.0 & 34.5 & 40.8 & 57.5 \\
\hline $\begin{array}{l}\text { sources self-assessment } \\
\text { Identified nonpoint source } \\
\text { pollution during the }\end{array}$ & 68.7 & 25.8 & 54.2 & 38.3 \\
\hline self-assessment & 81.0 & 17.9 & 43.3 & 54.2 \\
\hline
\end{tabular}

grazing management practices included cross-fencing and other practices that facilitate improved control over time, intensity, and season of grazing. Road management included road stabilization, drainage, and improved culvert placement. Water quality control practices included manure management and facilities improvements on dairies, and water quality monitoring.

Respondents were asked how much of their own funds and cost-share program funds they invested in BMPs. Personal funds exceeded cost-share funding until the investment reached $\$ 2000$ (Fig. 2). The cost of BMPs has been an issue for landowners throughout the development of the CRWQMP and during the short courses. This result suggests that widespread BMP implementation requires a combination of private and cost-share resources. If the survey results are any indication of how those funds are combined, then respondents are willing to spend up to about $\$ 2000$ for implementing BMPs, whereas cost-share programs typically provide support on the order of $\$ 2000$ or more (Jon Gustafson, NRCS State Range Conservationist, personal communication, January 2004). While our survey showed that short course participants are making use of cost-share programs, only 98 respondents had actually secured cost-share funding; $66 \%$ from USDA programs, and the remainder from local or state agencies.

Although there is potential for respondents to respond strategically by exaggerating BMP implementation, 98 respondents indicated that they received cost-share funding from USDA or other agencies. These cost-share programs, such as the Environmental Quality Incentive Program, require documentation of BMP implementation and effectiveness (NRCS 2004). Independent documentation of watershed management success stories by Macon (2001) and NPSPCP

Table 5. Nonpoint sources of pollution identified during selfassessments by respondents and their rate of best management practice implementation.

\begin{tabular}{lcc}
\hline Nonpoint sources & \multicolumn{2}{c}{ Implemented best management practices $(\%)$} \\
\cline { 2 - 3 } of pollution & Yes $(n=252)$ & No $(n=120)$ \\
\hline Sediment & 70 & 35 \\
Riparian damage & 36 & 14 \\
Nutrient & 22 & 10 \\
Pathogen & 12 & 3 \\
Heat & 13 & 5 \\
\hline
\end{tabular}




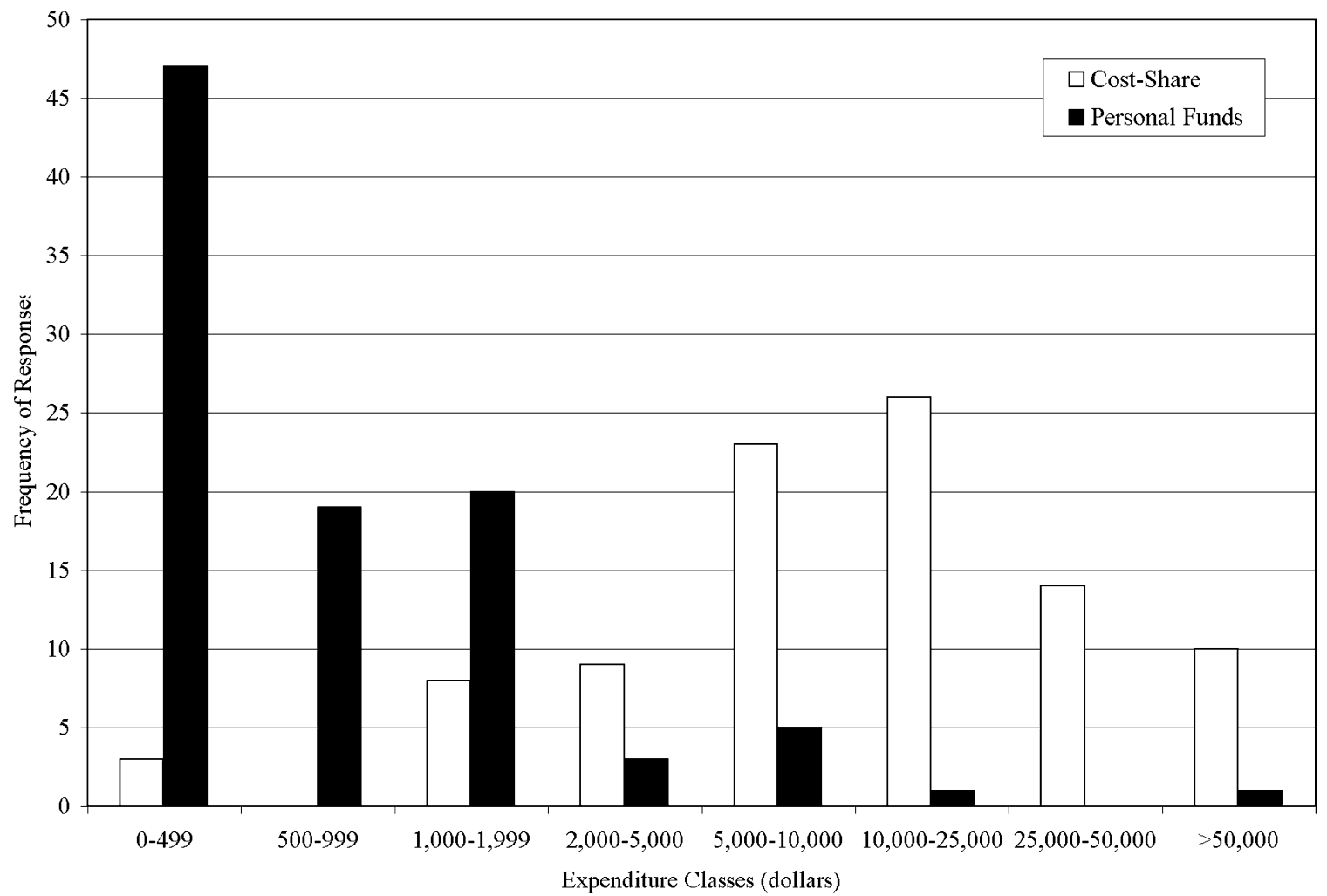

Figure 2. Money spent on best management practice implementation.

(2001) also supports survey responses. Most of the ranches highlighted in these reports had completed a ranch water quality plan during the RWQP Short Course.

\section{Respondent Motivation}

Like agricultural producers in the Rural Clean Water Program (EPA 1990), avoiding regulation and supporting industry initiatives were among the motivations to participate in this voluntary program. Respondents were asked their reasons for taking the short course and for implementing BMPs. Whether or not they implemented BMPs, the majority of the respondents selected avoiding regulation, learning about nonpoint source pollution, supporting this industry water quality initiative, and learning about regulations (Table 2). More than $60 \%$ of the respondents who implemented BMPs did so to control nonpoint source pollution and to support industry water quality initiatives (Table 6). Only 50\% responded that they implemented BMPs to avoid regulation. These responses suggest that avoiding regulation was the primary motivator for taking the short course, but after learning about nonpoint source pollution and completing a plan and self-assessment, controlling nonpoint source pollution became more important.

Ranchers are concerned that state regulation means a loss of freedoms and liberties (Huntsinger and Fortman 1990). Avoiding regulation has been a theme for rangeland owners and managers from the beginning of this voluntary program and is a primary reason stated for taking the short course. During the short course respondents learned that planning and implementing BMPs that targeted pollution sources, found during their self-assessment, was the most likely means of avoiding regulation. Therefore, it is not surprising that controlling nonpoint source pollution is the main reason respondents implemented BMPs because it was perceived as a means for avoiding regulation.

Leaders in the range livestock industry want the voluntary program to be successful and have encouraged their membership to attend the short course. Thus support for industry initiatives was a common reason for taking the short course and implementing BMPs. Respondents could have strategically answered questions to make this voluntary program look favorable. However, the level of plan completion, self-assessment, and BMP implementation suggests that the short course accomplishments are real, and respondents were motivated to make changes that would reduce nonpoint source pollution and avoid regulation.

\section{CONCLUSIONS AND MANAGEMENT IMPLICATIONS}

Identification of pollution sources, completion of plans, and documentation of BMP implementation are important

Table 6. Reasons cited by respondents for implementing best management practices.

\begin{tabular}{lc}
\hline Reason & Respondents (\%) \\
\hline To control nonpoint source pollution & 68 \\
To support industry water quality initiative & 63 \\
To avoid regulation & 50 \\
Other & 36 \\
To comply with nonpoint source regulations & 35 \\
\hline
\end{tabular}


measures of voluntary program success. Survey responses show that participants in this voluntary program are meeting the evaluation indicators established by California's range livestock industry to document implementation of the clean water program. They are participating in short courses, and completing nonpoint source self-assessments and ranch water quality plans, and implementing BMPs supported by private and cost-share funding. Landowners participating in voluntary programs usually self-document BMP implementation with no formal reporting process, thus protecting their confidentiality. Without formal reporting, regulatory agencies remain uncertain of industry-initiated voluntary program accomplishments. However, the results of this survey confirm that industryinitiated voluntary pollution control programs, supported by education, can result in implementation of BMPs. Evaluation surveys are an alternative to formal reporting that protects confidentiality while documenting program success. Several state and national voluntary clean water initiatives have been evaluated using social survey procedures (EPA 1990, GAO 1995, Richards and George 1996). All of these reports reconfirm the importance of education for generating awareness and behavioral change by participants in voluntary programs.

The total potential nonfederal rangeland in California is about 24 million acres (FRAP 2004). While this voluntary program has successfully influenced the management of about 1.5 million acres of nonfederal rangeland, it is not the only way to complete plans or implement BMPs. Rangeland owners are addressing nonpoint source pollution through conservation planning and cost-share contracts developed with USDA NRCS and other agencies. Additionally, private consultants are developing management plans that address clean water issues for corporate landowners such as oil companies, watershed groups, and various conservancies and foundations that manage rangeland.

\section{ACKNOWLEDGMENTS}

We greatly appreciate the University of California Cooperative Extension Farm Advisors and Specialists, staff from USDA Natural Resource Conservation Service, and several other state agencies, who were organizers and instructors for the 51 Ranch Water Quality Planning Short Courses that are documented in this report. Most of all, we thank the ranch owners and managers who attended these short courses and then implemented best management practices.

\section{LITERATURE CITED}

[AAPOR] American Association for Public Opinion Research. 2000. Standard definitions: Final dispositions of case codes and outcome rates for surveys. Lenexa, KS: AAPOR.

Brunson, M. D., D. T. Yarrow, S. Roberts, D. Guynn, JR., and M. Kuhns. 1996. Nonindustrial private forest owners and ecosystem management: can they work together? Journal of Forestry 94:14-21.

Coppock, L. D., And A. H. BiRkenfeld. 1999. Use of livestock and range management practices in Utah. Journal of Range Management 52:7-18.

Didier, E. A., and M. W. Brunson. 2004. Adoption of range management innovations by Utah ranchers. Journal of Range Management 57:330-336.

Dilıman, D. A. 2000. Mail and internet surveys: the tailored design method. New York, NY: John Wiley \& Sons, Inc.
[EPA] US Environmental Protection Agency. 1990. Rural clean water program, lessons learned for a voluntary non-point source control experiment. EPA No. 440/4-90-012. Washington, DC: EPA. 29 p.

[EPA] US Environmental Protection Agency. 2003. National management measures to control non-point source pollution in agriculture. EPA No. 841-B-03-004. Washington, DC: EPA. p 129-156.

Ewing, R. A., N. Tosta, R. Tuazon, L. Huntsinger, R. Marose, K. Nielson, R. Motroni, AND S. TURAN. 1988. California's forests and rangelands: growing conflict over changing uses. California Department of Forestry and Fire Protection. Sacramento, CA: Anchor Press. 99 p.

Fernandez-Gimenez, M. E., G. Ruyle and S. J. McClaran. 2005. An evaluation of Arizona Cooperative Extension's Rangeland Monitoring Program. Rangeland Ecology and Management 58:89-98.

Fliegel, F. C. 1993. Diffusion research in rural sociology. Westport, CT: Greenwood Press.

[FRaP] Fire and Resource Assessment Program. 2004. The changing California: Forest and range assessment 2003. Sacramento, CA: California Department of Forestry and Fire Protection. p 23-25.

GeORGE, M., AND L. Jolley. 1995. Management measures and practices. Rangeland Watershed Program Fact Sheet No. 9. Davis, CA: California Rangelands Research and Information Center, University of California. $5 \mathrm{p}$.

Gough, G., M. R. George, N. McDougald, and L. Jolley. 1998. Developing California's rangeland water quality management plan. In: D. F. Potts (ED.). Proceedings of the American Water Resources Association (AWRA) Special Conference in Rangeland Management and Water Resources. Reno, NV: AWRA. p 187-190.

[GA0] Government Accounting Office. 1995. Agriculture and the environment, information on the characteristics of selected watershed projects. Report to the U.S. Senate Committee on Agriculture, Nutrition, and Forestry. $65 \mathrm{p}$.

Huntsinger, L., and L. P. Fortmann. 1990. California's privately owned oak woodlands: owners, use, and management. Journal of Range Management 43:147-152.

Huntsinger, L., L. Buttolph, And P. Hopkinson. 1997. Ownership and management changes on California hardwood rangelands: 1985-1992. Journal of Range Management 50:423-430.

Jacobson, S., and S. Marynowski. 1997. Public attitudes and knowledge about ecosystem management on Department of Defense land in Florida. Conservation Biology 11:770-781.

Kraft, S., C. Lant, and K. Gillman. 1996. WQIP: an assessment of its chances for acceptance by farmers. Journal of Soil and Water Conservation 51: 494-498.

Kreuter, U. P., H. E. Amestoy, D. N. Ueckert, and W. A. McGinty. 2001. Adoption of Brush Busters: results of Texas county extension survey. Journal of Range Management 54:630-639.

LEwIS, G. 1995. Private property rights: the conflict and the movement. Journal of Forestry 93:25-26.

Lewis, D. J., K. W. Tate, and J. M. Harper. 2001a. Sediment delivery inventory and monitoring. Rangeland Monitoring Series, Publication No. 8014. Oakland, CA: Division of Agriculture and Natural Resources, University of California. $14 \mathrm{p}$.

Lewis, D. J., K. W. Tate, J. M. Harper, and J. Price. 2001b. Survey identifies sediment sources in North Coast rangelands. California Agriculture 55: 32-38.

LoHR, S. L. 1999. Sampling: Design and analysis. Pacific Grove, CA: Duxbury Press.

MACON, D. 2001. Grazing for change, range and watershed management success stories in California. Auburn, CA: Ag Resource Solutions. 35 p.

[NRCS] Natural Resources Conservation Service. 2004. California 2004 Environmental Quality Incentives Program (EQIP). Davis, CA: NRCS.

[NPSPCP] Non-point Source Pollution Control Program. 2001. Non-point source range management. Sacramento, CA: NPSPCP, State Water Resources Control Board. 6 p.

Reading, R. P., T. W. Clark, and S. Kellert. 1994. Attitudes and knowledge of people living the Greater Yellowstone Ecosystem. Society of Natural Resources 7:349-365. 
Richards, R., and M. R. George. 1996. Evaluating changes in range management practices though extension education. Journal of Range Management 49:76-80.

[SWRCB] State Water Resources Control Board. 1995. California Rangeland Water Quality Management Plan. Sacramento, CA: SWRCB.

[SWRCB] State Water Resources Control Board. 2000. Plan for California's Nonpoint Source Pollution Control Program. Sacramento, CA: SWRCB.

[SWRCB] State Water Resources Control Board. 2002. Clean Water Act Section 303(d) list of water quality limited segments. Sacramento, CA: SWRCB. $196 \mathrm{p}$.
[SWRCB] State Water Resources Control Board. 2004. Porter-Cologne Water Quality Control Act. Sacramento, CA: SWRCB. $137 \mathrm{p}$.

WHITE, L. D. 1987. Technology transfer and total ranch management. In: R. S. White and R. E. Short (EDS.). Proceedings of the Fort Keogh Research Symposium: Achieving efficient use of rangeland resources. Bozeman, MT: Montana Agricultural Experiment Station. p 125-128.

Workman, J. P. 1986. Range economics. New York, NY: MacMillan, Inc.

ZEPADA, L. 1994. Simultaneity of technology adoption and productivity. Journal of Agricultural Resource Economics 19:46-57. 